\section{History of Chronic Periodontitis Is a High Risk Indicator for Peri-Implant Disease}

\author{
Priscila Ladeira Casado ${ }^{1}$, Marcelo Constante Pereira², Maria Eugenia Leite \\ Duarte $^{3}$, José Mauro Granjeiro ${ }^{4}$
}

\author{
'Center of Clinical Research - \\ Orthopedics and Traumatology \\ National Institute - INTO - Rio \\ de Janeiro, RJ, Brazil and Clinical \\ Research Unit and Biology \\ Institute, Federal Fluminense \\ University, Niterói, RJ, Brazil \\ ${ }^{2}$ Veiga de Almeida University, \\ Rio de Janeiro, RJ, Brazil \\ ${ }^{3}$ Center of Clinical Research - \\ Orthopedics and Traumatology \\ National Institute - INTO - Rio \\ de Janeiro, RJ, Brazil \\ ${ }^{4}$ Cell Therapy Center, Clinical \\ Research Unit and Biology \\ Institute, Federal Fluminense \\ University and National Institute \\ of Metrology, Niterói, RJ, Brazil \\ Correspondence: Profa. Dra. Priscila
Ladeira Casado, Avenida Brasil
500, Anexo IV, Divisão de Pesquisa
20940-070, Rio de Janeiro, RJ,
Brasil. Tel: +55-21-2134-5014.
e-mail:pcasado@into.saude.gov.br
}

Key Words: chronic periodontitis, diagnosis, mucositis, peri-implantitis.

\section{Introduction}

In 2008, the Sixth European Workshop on Periodontology (1) presented a series of risk indicators for implant survival, such as lack of oral hygiene, diabetes, smoking and history of periodontitis, which were related to the development of peri-implant disease (PID). The previous history of periodontitis has shown to influence the success rate in Implant Dentistry (2). Patients without history of periodontitis present an average of $96.5 \%$ of implant survival in comparison with $90.5 \%$ of survival in individuals with history of periodontitis (3). Curiously, periodontal disease is the main cause of dental loss in approximately $60 \%$ of the Brazilian population aged between 35 and 44 years needing oral rehabilitation (4).

The human oral cavity is colonized by at least 600 different bacterial species, which are most innocuous. From these, at least, 400 species are found in the subgingival region (5) and, therefore, the periodontal pockets act as a reservoir for periodontal pathogens (6).

The transmission of periodontal pathogens from residual dentition to the implant has been reported. In patients with a high number of periodontal pathogens there is an increased risk of cross infection between periodontal and peri-implant sites (7). Several studies $(8,9)$ have shown that the periodontal pathogens Actinobacillus actinomycetemcomitans (Aa), Porphyromonas gingivalis
(Pg), Prevotella intermedia (Pi), Prevotella nigrescens, Bacteroides forsythus and Treponema denticola (Td) can be found in the areas of the PID.

One month after reopening surgery to expose the implants, periodontal pathogens can be detected around implant surface and, in the same individual, the same bacteria found in the residual periodontal pocket are found in the peri-implant sulcus (7). However, not only the presence of these pathogens is capable of causing disease. The local immune response, determined by the interaction among molecules and cells, can promote greater protection or susceptibility to several inflammatory and infectious diseases, including PID.

In periodontitis, the local inflammatory reaction to bacterial infection activates the innate immune system, resulting in the release of an array of cytokines and other mediators and propagation of inflammation through the gingival tissues $(10,11)$. The failure to encapsulate this "inflammation front" within gingival tissue results in the expansion of the response to adjacent alveolar bone (10). Moreover, the host response is influenced by several possible risk factors including genetic factors. Previous studies indicated that chronic periodontitis (CP) may have a genetic background $(12,13)$, as well as PID $(14,15)$.

Patients who receive implants and have history of previous periodontitis have previously shown tissue- 
destructive inflammatory response in the periodontium, and in the presence of change in the microbiota an exacerbated inflammatory response may be trigged leading to the development of PID and consequently, the loss of the implant (16). A recent study compared the clinical and immunological conditions (IL-1 $\beta$ and TNF- $\alpha$ ) in periodontal and peri-implant tissues of two types of platform implants and a positive correlation between the concentrations of IL-1 $\beta$ and TNF- $\alpha$ and bone loss around the teeth and implant was found (17). Therefore, the aim of this study was to evaluate if patients with history of $\mathrm{CP}$ are more susceptible to mucositis and peri-implantitis than patients without history of CP.

\section{Material and Methods}

\section{Patient Selection}

A sample of 215 unrelated, partially edentulous subjects, 148 female and 67 male, with mean age of $55.0 \pm 12.5$, presenting a total of 754 osseointegrated endosseous implants, were recruited for this study from the patient pool treated at the Dental Clinics of the Dental School, Veiga de Almeida University, during 1 year. The patients were from the southeastern region of Brazil. All subjects signed a consent form, which was approved by Veiga de Almeida University - Ethical Board recommendations (Registration \#238/10), after being informed of the nature of the study. The baseline clinical parameters for the subject population are presented at Table 1. Individuals involved in this study did not have meed of the following exclusion criteria: diseases of the oral hard or soft tissues except caries and periodontal disease; use of orthodontic appliances; need for premedication for dental treatment; chronic usage of anti-inflammatory drugs; a history of diabetes, hepatitis or HIV infection; immunosuppressive chemotherapy; history of any disease known to severely compromise immune function; present acute necrotizing ulcerative gingivitis; current pregnancy or lactation. The additional inclusion criterions were: to have at least one osseointegrated endosseous implant, to have immediate postoperative radiography showing the vertical bone level around implant in order to compare bone level after osseointegration period, to have periapical radiography showing periodontal status before implant placement and to be under maintenance care being recalled regularly. The function time of the implants ranged from 1 to 8 years.

\section{Peri-implant Disease Diagnosis}

All peri-implant regions were evaluated clinically and radiographically. Clinical examination of the peri-implant sites consisted of visual inspection and palpation, analysis of mucosa inflammation, edema, probing pocket depth (PPD), bleeding on probing and spontaneous bleeding in four aspects (mesial, buccal, distal and lingual/palatine) and implant mobility. The conventional periapical radiography, using the paralleling technique, measured the presence of vertical bone loss around the implants, by measuring the height of peri-implant bone compared to initial radiography immediate after implant placement. According to the clinical and radiographic characteristics of the peri-implant sites, patients were characterized as having healthy sites (Control group) - no clinical signs of inflammation in the peri-implant mucosa and no signs of pathological bone loss -, or peri-implant disease (PID group) - presence of bleeding on probing, red mucosa and swelling and/or radiographic signs of pathologic bone loss in at least one region (Table 2 ).

Physiological bone loss was characterized considering the normal bone loss of $1 \mathrm{~mm}$ at the first year after implant placement and $0.2 \mathrm{~mm}$ for subsequent years (18). According to the implant osseointegration period the total amount of bone loss was calculated based on difference between immediate postoperative radiography and diagnosis radiography (at the moment of peri-implant examination). If the total of bone loss was superior to $1 \mathrm{~mm}$ and $0.2 \mathrm{~mm}$ for year, patient was considered with periimplantitis and included in PID group.

In patients with more than *PID: Peri-implant disease. ${ }^{* *}$ :Systemic disease includes high blood pressure, cardiovascular disease

and asthma. \#: Chi-squared test. 9: Student's t-test. OR: odds ratio. $\mathrm{Cl}$ : confidence interval.

Table 1. Baseline clinical parameters of the population

\begin{tabular}{lccccc} 
Non-smoking & $194(90.2 \%)$ & $116(89.9 \%)$ & $78(90.7 \%)$ & & \\
Smoking & $21(9.3 \%)$ & $13(10.1 \%)$ & $8(9.3 \%)$ & & $1.09(0.40-3.04)$ \\
Systemic disease $* * \#$ & $63(29.3 \%)$ & $42(32.6 \%)$ & $21(24.5 \%)$ & 0.19 & $0.67(0.35-1.29)$ \\
\hline
\end{tabular}

one implant, the peri-implant 
region that showed clinical and/or radiographic signs of disease was used in order to characterize the individual in PID group. Patients in the Control group had no disease in all peri-implant regions.

\section{Diagnosis of Chronic Periodontitis}

The diagnosis of CP was established on the basis of radiographic parameters, including periapical radiographic analysis showing horizontal bone resorption before implant placement, in order to differentiate chronic from aggressive periodontitis, and assessment of past dental history. Patients with $\mathrm{CP}$ had to present bleeding on probing and pocket depth $\geq 4 \mathrm{~mm}$ in at least 30\% of the total sites at some period of the development of the disease, before implant placement. All data were assessed in patients chart.

All patients were characterized as with or without history of $\mathrm{CP}$, according to previous clinical and radiographic characteristis. All patients in the $\mathrm{CP}$ group had been treated for $\mathrm{CP}$ and were under maintenance being recalled regularly.

\section{Statistical Analysis}

All data were analyzed considered the total number of patients. Nominal variables were expressed as frequencies

Table 2. Peri-implant status of the patients between groups, the chi-squared test was performed. Numeric variables were expressed as mean and standard deviation. Then, after Shapiro-Wilk test showed normal distribution among variables, parametric data were evaluated by ANOVA and thereafter subjected to the Student's t-test. Non-parametric data were evaluated by the Mann-Whitney test. Values of $p<0.05$ were considered statistically significant. Statistical analyses were performed using STATA 11.1 (StataCorp, College Station, TX, USA).

\section{Results}

The clinical results considered the presence of PID and $\mathrm{CP}$ in all subjects. Initially, the patients were divided in two groups in order to evaluate the presence of PID. Baseline characteristics (Table 1) showed that patients in the Control and PID groups were not significantly different ( $p>0.05$ ) considering age, gender, smoking habit and presence of systemic disease.

Specific peri-implant status of patients were analyzed (Table 2) and parameters related to the diagnosis of PID were significantly higher in the PID group, including bleeding on probing and spontaneous bleeding ( $p<0.001$ for both), PPD ( $p=0.04)$ and bone loss $(p=0.05)$. It was observed a high prevalence of EH implants in the PID group. In contrast,

\begin{tabular}{|c|c|c|c|c|c|}
\hline Peri-implant status & Total $(n=215)$ & $\begin{array}{l}\text { Control group } \\
(\mathrm{n}=129)\end{array}$ & $\begin{array}{l}\text { PID group } \\
(\mathrm{n}=86)\end{array}$ & $p$-value & $\mathrm{OR}(\mathrm{Cl})$ \\
\hline Bleeding on probing ${ }^{\#}$ & $70(32.5 \%)$ & $19(14.7 \%)$ & 51 (59.3\%) & $0.00001^{*}$ & $8.44(4.21-17.08)$ \\
\hline Spontaneous bleeding ${ }^{\#}$ & $11(5.1 \%)$ & 0 & $11(12.8)$ & $0.00001^{*}$ & $2.84(2.35-3.43)$ \\
\hline $\operatorname{PPD}(\mathrm{mm})^{\uparrow}$ & $2.7 \pm 0.9$ & $3.02 \pm 0.68$ & $2.4 \pm 1.38$ & $0.04^{*}$ & ----- \\
\hline Bone loss $(\mathrm{mm})^{\uparrow}$ & $1.91 \pm 2.33$ & 0 & $2.23 \pm 2.55$ & $0.05^{*}$ & ----- \\
\hline Mobility \# (presence) & $5(2.3 \%)$ & 0 & $5(5.8 \%)$ & & \\
\hline \multicolumn{6}{|l|}{ Implant- platform Type ${ }^{\#}$} \\
\hline $\mathrm{EH}$ & $361(47.9 \%)$ & $166(43.6 \%)$ & $195(52.3 \%)$ & \multirow{4}{*}{$0.03^{*}$} & \multirow{4}{*}{----- } \\
\hline $1 \mathrm{H}$ & $64(8.5 \%)$ & $29(7.6 \%)$ & $35(9.4 \%)$ & & \\
\hline MC & $286(37.9 \%)$ & $161(42.2 \%)$ & $125(33.5 \%)$ & & \\
\hline Others & $43(5.7 \%)$ & $25(6.6 \%)$ & $18(4.8 \%)$ & & \\
\hline \multicolumn{6}{|l|}{ Implant region\# } \\
\hline Superior & $359(47.6 \%)$ & $169(44.3 \%)$ & $190(50.9 \%)$ & \multirow{2}{*}{0.07} & \multirow{2}{*}{$1.30(0.97-1.75)$} \\
\hline Inferior & $395(52.4 \%)$ & $212(55.7 \%)$ & $183(49.1 \%)$ & & \\
\hline $\begin{array}{l}\text { Osseointegration } \\
\text { period (months) }\end{array}$ & & $64.97 \pm 50.36$ & $69.5 \pm 80.8$ & 0.08 & ----- \\
\hline
\end{tabular}

PPD: pocket probing depth - mean from 4 aspects analyzed (mesial, distal, buccal, lingual/palatal); EH: external hexagon. $1 \mathrm{H}$ : internal hexagon. $\mathrm{MC}$ : morse cone. ${ }^{*} \mathrm{p}$-value $<0.05$ are considered statistically significant. $\mathrm{OR}=$ odds ratio. $\mathrm{Cl}=$ confidence interval. \#: Chi-square test. I: Student t-test. OR: odds ratio. $\mathrm{Cl}$ : confidence interval. 
in the Control group there was higher incidence of $\mathrm{MC}$ implants. Implant region and osseointegration period did not differ between the groups.

$\mathrm{CP}$ history was considered in patients presenting PID or not (Table 3 ) and it was clearly identified that patients with $\mathrm{CP}$ history had almost 4 times more chance of developing PID compared with patients with healthy periodontium (OR 3.95). There was a high incidence of PID in patients with $C P$ history $(p<0.001)$; while for every 4 patients without $\mathrm{CP}$ history only 1 can develop PID, in the presence of $\mathrm{CP}$ for every 1.7 patient 1 can develop PID.

The cross-information between peri-implant status and history of CP (Table 4) was accessed in order to understand if patients with $\mathrm{CP}$ show specific differences around implant. It was observed that patients with $\mathrm{CP}$ history showed significantly higher peri-implant bleeding on probing $(p=0.002)$ and peri-implant bone loss $(p=0.004)$ compared with those with healthy periodontium. However, peri-implant spontaneous bleeding, PPD and implant mobility were not different between patients in $\mathrm{CP}$ and Control groups.

\section{Discussion}

Current rates show an increasing incidence of PID in patients rehabilitated with endosseous implants (1). Recent studies have investigated the influence of periodontitis in implant survival $(3,6)$. Therefore, the aim of this study was to assess if $\mathrm{CP}$ history is associated with the presence of PID in patients under periodontal/peri-implant maintenance, which is related to the following important question in Implant Dentistry: have patients susceptible to $\mathrm{CP}$ an increased risk of developing PID and potential loss of implant?

The main causes of implant failures are: low quality and quantity of bone neoformation; diseases that affect bone repair; unfavorable habits such as bruxism and smoking; inappropriate surgical technique causing lack of primary stability; inappropriate denture and type of implant surface (19). However, even when these failure causes are excluded, PID can be observed. Unfortunately, it seems that we are still far from understanding the true causes of implant failures after successful initial osseointegration. Therefore, current studies have proposed other theories to explain implant failure, including the theory of vulnerability that attributes failures to poor oral hygiene and advanced periodontal disease (19). In the present cross-sectional study, it was evaluated the influence of a specific type of periodontal disease - CP - which is a highly common disease in the Brazilian population, as a possible cause of implant failure related to PID.

Microbial etiology of periodontitis is well established. Studies show that partially edentulous patients have an increased risk of crossinfection between periodontal and peri-implant sites $(7,16)$. However, it seems that the presence of periodontal pathogens in the peri-implant sulcus does not necessarily result in tissue destruction (20), which indicates that other systemic or genetic factors related to the patients are involved in implant survival. This fact would also explain why completely edentulous patients with previous history of periodontitis develop periimplant bone loss even in the absence of cross infection between the periodontal and peri-implant sulcus (9).

The correlation between biochemical markers of inflammation and clinical parameter of health and disease around the implant are the focus of recent studies 
(3). In the presence of periodontal pathogens, the immune response may trigger a higher or lower degree of cytokine production or interfere with its physiology (14). In CP, the pro-inflammatory immune response is highly related to bone loss. Therefore, even edentulous patients and those under maintenance of periodontal and peri-implant health, who are considered as free of active infection (e.g.: the patients in this study), the individual inflammatory pattern inherent to its genetic characteristic may trigger periimplant bone loss, as it occurs in periodontitis.

Another important aspect to be considered is that, anatomically, despite the gingival tissue around the tooth and mucosa around the implants presenting similar reaction to the presence of bacterial plaque (21), the peri-implant mucosa seems to be less capable of resolving lesions associated with plaque in comparison with the gingiva. Thus, several studies report a remarkable difference between lesions present in the periodontium and in the peri-implant tissue $(22,23)$. The inflammatory cell infiltrate in the periimplant mucosa is greater and it extends more apically when compared with a similar lesion in the gingival tissue (24). Hultin et al. (16) reported that a local specific inflammatory reaction related to the bacterial presence occurs around $\dot{s}$ the implants leading to marginal bone loss and infection (peri-implantitis) that is, an inflammatory activity in the periodontium could cause irreversible damages to the periimplant tissue. This fact corroborates the present study, which showed that an incidence of PID is 4 times higher in patients with history of $\mathrm{CP}$ than in patients who have never manifested periodontitis, irrespective of the gender, age and the region of implant placement. The correlation between CP and PID (mucositis and periimplantitis) is highly significant $(p<0.0001)$.

Also, the analysis of the peri-implant status in patients with and without $\mathrm{CP}$ history showed that peri-implant soft tissue as well as peri-implant bone are markedly affected in patients with CP. Peri-implant bleeding on probing and bone loss were significantly higher in the $\mathrm{CP}$ group. It is likely that a similar inflammatory reaction that acted around tooth, leading to tooth loss, could be acting around the implant. It must be considered that the tooth was lost, but the gingiva, bone and oral microenvironment remain the same, in the same patient, and this could explain why patients with $\mathrm{CP}$ history showed more prei-implant bleeding on probing and bone loss in the present study.

Considering that the Brazilian population has prognostic periodontitis as etiology of dental loss (4), increasing the number of rehabilitations with dental implants, and that these individuals, as well as having periodontal microbiota, are capable of triggering an excessively destructive inflammatory response to the bone support (25), we must ask what should the attitude of dentists be towards a patient with $\mathrm{CP}$ history when using implants for rehabilitation of these patients.

First, this study suggests that before and after implant placement surgery, treatment must not only be considered perse, but periodontal therapy should be carried out as well. During the pre-operative stage, it is essential to perform procedures such as removing areas of microbial retention (e.g.: poorly fitted dentures, restorations in excess) and supra and subgingival scaling, and provide oral hygiene guidance. During and after surgery, it is indicated to shorten the evaluation intervals, performing procedures with the least stress possible to the bone and gingival tissues, and reduce or eliminate any rehabilitation with implant-supported dentures that retain plaque or occlusal overload.

Future studies considering the genetic and protein pattern in situ are important in determining if the levels of key molecules involved in periodontium destruction are sustained around implants starting PID or implant loss.

In conclusion, patients with $\mathrm{CP}$ history are strong candidates for developing PID and possible bone loss, irrespective of the gender or the region of implant placement. The best way to minimize these consequences is to consider the patient's pattern, shortening the followup intervals and eliminating restorations, dentures and prosthetic pieces, that retain plaque in order to achieve successful results.

\section{Resumo}

0 indice de sucesso em implantodontia varia significantemente entre indivíduos apresentando história prévia de periodontite. 0 objetivo deste estudo foi avaliar se pacientes com história de periodontite crônica (CP) são mais susceptíveis ao desenvolvimento de doença peri-implantar (PID) do que pacientes sem história de CP. Duzentos e quinze individuos, sob manutenção periodontal, apresentando 754 implantes osseointegrados, foram selecionados para este estudo. Os pacientes foram divididos em 2 grupos de acordo com o estado peri-implantar: Grupo Controle (pacientes sem PID, $n=129$ ) e Grupo PID (pacientes com PID, $n=86$ ). Todas as regiões peri-implantares foram clinicamente avaliadas, incluindo análise da inflamação na mucosa, edema e mobilidade do implante. Radiografias periapicais avaliaram a presença de perda óssea peri-implantar. De acordo com as características clínico/radiográficas, pacientes nos Grupos Controle e PID foram diagnosticados como tendo CP ou não. As variáveis nominais foram avaliadas pelo teste do qui-quadrado. A distribuição das variáveis numéricas foi avaliada pelo teste de Shapiro-Wilk. 0 Teste t e o teste de Mann-Whitney foram utilizados para analisar a significância dos dados, em caso de distribuição normal e não-normal, respectivamente. Valor de $p<0,05$ foi considerado significante. 0 s resultados mostraram que há correlação altamente significativa entre história de CP e presença PID $(p<0,0001)$, com risco 4 vezes maior de desenvolver PID para pacientes com $\mathrm{CP}$. Pacientes com CP também mostraram maior sangramento à sondagem $(p=0,002)$ e perda óssea peri-implantar $(p=0,004)$ quando comparados a pacientes sem CP. Concluímos que história de periodontite crônica é um fator de alto risco ao desenvolvimento de doença peri-implantar, independente do gênero ou região de instalação do implante.

\section{References}

1. Lindhe J, Meyle J. Peri-implant diseases: consensus report of the sixth European workshop on Periodontology. J Clin Periodontol 
2008;35:282-285.

2. Renvert $\mathrm{S}$, Roos-Jansâker $A M$, Lindahl $C$, Renvert $H$, Persson GR. Infection at titanium implants with or without a clinical diagnosis of inflammation. Clin Oral Implant Res 2007;18:509-516.

3. Heitz-Mayfield LA. Peri-implant diseases: diagnosis and risk indicators. J Clin Periodontol 2008;35:292-304.

4. SB Brazil Project. Dental health conditions of the Brazilian population: main results. Brasilia 2003;36-40.

5. Paster BJ, Boches SK, Galvin JL, Ericson RE, Lau CN, Levanos VA, et al.. Bacterial diversity in human subgingival plaque. J Bacteriol 2001;183:3770-3781.

6. Hardt CR, Grindahl K, Lekholm U, Wennstrom JL. Outcome of implant therapy in relation to experienced loss of periodontal bone support: a retrospective 5-year study. Clin Oral Implants Res 2002;13:488-494.

7. Papapanou PN, Baelum V, Luan WM, Madianos PN, Chen X, Fejerskov O, et al.. Subgingival microbiota in adult Chinese: prevalence and relation to periodontal disease progression. J Periodontol 1997;68:651-666.

8. Ximenez-Fyvie LA, Haffajee AD, Socransky SS. Microbial composition of supra and subgingival plaque in subjects with adult periodontitis. J Clin Periodontol 2000;27:722-732.

9. Casado PL, Otazu IB, Balduino A, de Mello W, Barboza EP, Duarte ME. Identification of periodontal pathogens in healthy periimplant sites. Implant Dent 2011;20:226-235.

10. Campos BO, Fischer RG, Gustafsson A, Figueredo CMS. Effectiveness of non-surgical treatment to reduce IL-18 levels in the gingival crevicular fluid of patients with periodontal disease. Braz Dent J 2012;23:428432.

11. Téllez N, Aguilera N, Quinonez B, Silva E, González LE, Hernandez L. Arginine and glutamate levels in the gingival crevicular fluid from patients with chronic periodontitis. Braz Dent J 2008;19:318-322.

12. Trevilatto $P C$, Scarel-Caminaga RM, de Brito RB Jr, de Souza AP, Line SRP. Polymorphism at position 174 of IL-6 gene is associated with susceptibility to chronic periodontitis in a Caucasian Brazilian population. J Clin Periodontol 2003;30,438-442.

13. Zitzmann NU, Berglundh T. Definition and prevalence of peri-implant diseases. J Clin Periodontol 2008;35:286-291.

14. Campos MIG, Santos MCL, Trevilatto PC, Scarel-Caminaga RM, Bezerra FJ, Line SRP. Interleukin-2 and Interleukin-6 Gene Promoter Polymorphisms, and Early Failure of Dental Implants. Implant Den
2005; $14: 391-398$

15. Dirschnabel AJ, Alvim-Pereira F, Alvim-Pereira CC, Bernardino JF, Rosa EAR, Trevilatto PC. Analysis of the association of IL1B(C-511T) polymorphism with dental implant loss and the clusterization phenomenon. Clin Oral Implants Res 2011;22:1235-1241.

16. Hultin $M$, Gustafsson $A$, Hallstrom $H$, Johansson LA, Ekfeldt $A$, Klinge B. Microbiological findings and host response in patients with periimplantitis. Clin Oral Implants Res 2002;13:349-358.

17. Machtei EE, Oved-Peleg E, Peled M. Comparison of clinical, radiographic and immunological parameters of teeth and different dental implant platforms. Clin Oral Implants Res 2006;17:658-665.

18. Roos J, Sennerby L, Lekholm U, Jemt T, Grondahl K, Albrektsson T. A qualitative and quantitative method for evaluating implant success: a 5-year retrospective analysis of the Branemark implant. Int J Oral Maxillofac Implants 1997;12:504-514.

19. Toltusnov L. Dental implant success-failure analysis: a concept of implant vulnerability. Implant Dent 2006;15:341-346.

20. Boever $A L$, Boever JA. Early colonization of non-submerged dental implants in patients with a history of advanced aggressive periodontits. Clin Oral Implants Res 2006;17:8-17.

21. Pontoriero R, Tonelli MP, Carnevale G, Mombelli A, Nyman SR, Lang NP. Experimentally induced periimplant mucositis. A clinical study in humans. Clin Oral Implants Res 1994;5:254-259.

22. Ericsson L, Berglundh T, Marinello C, Lijenberg B, Lindhe J. Longstanding plaque and gingivitis at implants and teeth in the same dog. Clin Oral Implants Res 1992;3:99-103.

23. Lindhe J, Berglundh T, Ericsson J, Lijenberg B, Marinello C. Experimental breakdown of peri-implant and periodontal tissues. Clin Oral Implants Res 1992;3:9-16.

24. Leonhardt A, Dahlen G, Renvert S. Five-year clinical, microbiological and radiological outcome following treatment of peri-implantitis in man. J Periodontol 2003;74:1415-1422.

25. Heitz-Mayfield UA, Lang NP. Comparative biology of chronic and aggressive periodontitis vs peri-implantitis. Periodontol 2000 2010;53:167-181.

Received April 13, 2012 Accepted April 2, 2013 